\title{
GROWTH OF LULO (Solanum quitoense Lam.) PLANTS AFFECTED BY SALINITY AND SUBSTRATE ${ }^{1}$
}

\author{
SANDRALILIANAFLÓREZ², DIEGO MIRANDALASPRILLA ${ }^{3}$, BERNARDOCHAVES ${ }^{4}$, \\ GERHARD FISCHER ${ }^{5}$, STANISLAV MAGNITSKIY ${ }^{6}$
}

ABSTRACT - The effects of 0,30 and $60 \mathrm{mM} \mathrm{NaCl}$ and substrates (red peat, sand or 3:1:1 [w/w] mixture of peat, sand, or soil) on vegetative growth of lulo, an Andean fruit species, during 12 weeks were studied. The experiment was carried out by using $2000 \mathrm{~cm}^{3}$ of polypropylene plastic pots under greenhouse conditions. Plant height, number of leaves and nodes, leaf area, total plant dry matter (DM), and shoot/root ratio were evaluated. With the increase of salt concentration, the plant height, the number of leaves and nodes, the leaf areas and plant dry mass DM decreased, whereas shoot/root ratio increased. Sand grown lulo plants were most affected by salinity and presented total mortality at $60 \mathrm{mM} \mathrm{NaCl}$. On the other hand, plants held either in peat or in substrate mixture developed larger height, greater leaf and node numbers, higher leaf area and dry matter content. Shoot/root ratio in control (soil) and sand-grown plants $(30 \mathrm{mM} \mathrm{NaCl})$ was lower.

Index Terms: Lulo, naranjilla, salinity, $\mathrm{NaCl}$, plant height, leaf area, dry matter, peat, sand.

\section{CRESCIMENTO DE PLANTAS DE LULO (Solanum quitoense Lam.) AFETADAS POR SALINIDADE E SUBSTRATOS}

RESUMO - Durante 12 semanas, foi estudado o efeito de 0; 30 e $60 \mathrm{mM}$ de $\mathrm{NaCl}$ e dos substratos (turfa vermelha, ou de mistura de turfa, areia, ou solo 3:1:1 [w/w]) sobre o desenvolvimento vegetativo de lulo, uma espécie de fruto originária dos Andes. O experimento foi feito em condições de casa de vegetação, utilizando vasos plásticos de polipropileno de $2.000 \mathrm{~cm}^{3}$. Foram avaliadas as mudanças em altura de planta, número de folhas e nós, área foliar, massa seca total da planta (DM) e relação raiz parte aérea. Com o incremento da concentração salina, a altura de planta, o número de folhas e de nós, as áreas foliares e a massa seca da planta diminuíram, enquanto a relação parte aérea/raiz aumentou. As plantas de lulo cultivadas em areia foram as mais afetadas pela salinidade e apresentaram mortalidade total aos $60 \mathrm{mM}$ de NaCl . Assim, as plantas mantidas em turfa ou na mistura de substratos apresentaram maiores alturas, número de folhas e nós, áreas foliares e conteúdo de massa seca. A relação parte aérea/raiz foi mais baixa no controle (solo) e nas plantas cultivadas em areia $(30 \mathrm{mM} \mathrm{NaCl})$.

Termos para indexação: Solanum quitoense, salinidade, $\mathrm{NaCl}$, altura de planta, área foliar, massa seca, turfa, areia.

\section{INTRODUCTION}

Soil salinity is one of the most serious stress factors in the agriculture (Rains y Goyal, 2003), limiting growth and yield of many crops. More than $6 \%$ of the terrestrial surface is affected by salinity and sodicity (Munns, 2003). At least $20 \%$ of the worldwide arable land is endangered by excessive salt concentration (Ebert, 2000). Salinity has a two-fold effect on plants: the salt in the soil solution decreases the availability of water to the roots, and the salt taken up by the plant can be accumulated up to toxic levels in certain tissues. Both factors affect growth (Munns et al., 1995). Additionally, due to growth reduction in leaves and roots, the salts in soil solution decrease stomatal conductance and, consequently, photosynthesis (Munns, 1993).

For centuries, the lulo or "naranjilla" (Solanum quitoense Lam.) has been an immensely popular fruit in Colombia and
Ecuador, producing fruits all year-round (National Research Council, 1989). Colombian Andean farmers grow lulo between 1,800 and 2,500 m above sea level, mainly on rainy slopes (Angulo, 2006). The fruits are similar to tomato, but have yellowish-orange skin and green flesh. Covering 6,637 ha of production area, lulo is the most important Solanaceae fruit crop in Colombia (Tafur, 2006). However, in some production zones, the absence of fresh water for irrigation, as well as soil salinity limit its production.

Ebert et al. (1999) observed that treatments of lulo plants with 30 and $60 \mathrm{mM} \mathrm{NaCl}$ during 10 weeks reduced leaf dry matter by 6 and 15\%, respectively. These authors considered that lulo has a moderate tolerance to salinity because growth reduction in lulo was only $15 \%$ compared to $40 \%$ reduction in sensitive fruit species.

The methods of growth analysis are useful tools for describing plant response to environmental conditions (Hunt, 1982). Since the effects of salinity on lulo growth have not been investigated in Colombia, the aim of this study is to evaluate the

\footnotetext{
'(Trabalho 189-07). Recebido em: 03-08-2007. Aceito para pubicação em: 20-12-2007.

${ }^{2}$ Ing. Agr., Facultad de Agronomía, Universidad Nacional de Colombia, Bogotá. slflorezp@unal.edu.co. ${ }^{3}$ Prof. Asociado, M.Sc., Facultad de Agronomía, Universidad Nacional de Colombia, Bogotá. dmirandal@unal.edu.co. ${ }^{4}$ Prof. Asociado, M.Sc., Facultad de Agronomía, Universidad Nacional de Colombia, Bogotá. bchavesc@unal.edu.co. ${ }^{5}$ Prof. Asociado, Dr., Facultad de Agronomía, Universidad Nacional de Colombia, Bogotá. gerfischer@gmail.com. ${ }^{6}$ Prof. Asistente, Dr., Facultad de Agronomía, Universidad Nacional de Colombia, Bogotá. svmagnitskiy@unal.edu.co.
} 
influence of various $\mathrm{NaCl}$ concentrations and soil types on growth, leaf area, and shoot/root ratio, and results may be further used to recommend growth areas with appropriate salt concentrations for this crop.

\section{MATERIALS AND METHODS}

Two-month-year-old lulo (Solanum quitoense Lam., var. quitoense) plants originated from Subia region (latitude $4^{\circ} 31^{\prime} \mathrm{N}$ and longitude $74^{\circ} 20^{\prime} \mathrm{W}$, near Bogotá, Colombia) were transplanted to $2000 \mathrm{~cm}^{3}$ polypropylene plastic containers receiving drip irrigation in a plastic greenhouse $\left(15,6^{\circ} \mathrm{C}\right.$ average, $20,2^{\circ} \mathrm{C}$ medium maximum and $11,1^{\circ} \mathrm{C}$ medium minimum temperatures; $61 \%$ average, $73,8 \%$ medium maximum and $48,1 \%$ medium minimum relative humidity) at the National University of Colombia, Bogotá (2,556 m. a.s.l.). The individual area for plants established in the treatments was $634.5 \mathrm{~cm}^{2}$. Plastic containers were filled with blond peat, sand or a mixture of blond peat, sand and soil at a 3:1:1 (w/w) ratio and an absolute control - soilbased substrate with the following characteristics: $\mathrm{pH}$ 6.8, percentages of sand-slime-clay equivalent to 68-26-6, organic carbon $6.08 \%, \mathrm{~N} 0.52 \%, \mathrm{Ca} 196 \mathrm{mmol}_{\mathrm{c}} / \mathrm{kg}, \mathrm{Na} 0.8 \mathrm{mmol}_{\mathrm{c}} / \mathrm{kg}$, and CEC $318 \mathrm{mmol}_{\mathrm{c}} / \mathrm{kg}$. The distribution of the particle size of sand was the following: $>1 \mathrm{~mm}: 9 \% ; 0,250-1 \mathrm{~mm}: 30 \% ;<0,250 \mathrm{~mm}: 61 \%$, classified as fine sand. Oligotrophic peat moss (Fa. KlasmannDeilmann $\mathrm{GmbH}$, Geeste-Germany) with $\mathrm{pH}$ adjustment of 5.56.5 , organic matter content $90 \%$ and salt content $<0.5 \mathrm{~g} \mathrm{KCl} / \mathrm{L}$ with the following nutrient content was used: $20-50 \mathrm{mg} / \mathrm{L} \mathrm{N}, 30$ $60 \mathrm{mg} / \mathrm{L} \mathrm{K} \mathrm{O}_{2} \mathrm{O}$ and $40-80 \mathrm{mg} / \mathrm{L} \mathrm{Mg}$.

Plants were fertilized with $4 \mathrm{~g}$ of Basacote 13-6-16 $3 \mathrm{M}^{\circledR}$ (Fa. Compo). After a two-week adaptation period of transplanting, $\mathrm{NaCl}$ at a concentration of 0,30 , or $60 \mathrm{mM}$ was applied twice a week with normal irrigation.

During 12 weeks, one plant per replicate was taken every 8 days for measuring plant height, number of nodes and totally expanded leaves area (LI-COR 3100) and dry matter (dried at $60^{\circ} \mathrm{C}$ during $72 \mathrm{~h}$ ) of leaves.

Taking into account that evaluations were carried out during a short period of vegetative growth phase, the changes in growth obtained from the dry weight and leaf area analyses were fitted to an exponential model. The equation used was: $W=a \mathrm{e}^{\mathrm{b} T}$, where $\mathrm{W}$ is the total dry weight, coefficient $a$ is the value of $\mathrm{W}$ or $\log _{\mathrm{e}} W$ and corresponds to initial total dry weight when the growth rate $\mathrm{T}=0$ and coefficient $b$ is the rate of increase of $W$ or $\log _{\mathrm{e}} W$ (Hunt, 1982).

\section{RESULTS AND DISCUSSION}

From the second week of evaluation, high mortality of plants grown in sand treated with $\mathrm{NaCl}$ was observed. Applying $60 \mathrm{mM} \mathrm{NaCl}$ in sand substrate, all plants died until the $5^{\text {th }}$ week, thus, this treatment was excluded from the analyses. In the sand treatment with $30 \mathrm{mM} \mathrm{NaCl}$, the data was collected up to the eighth week. Supposedly, very low cation exchange, moisture and buffer capacities of sand (Hanan, 1998), as compared to other treatments, affected growth so severely that plants died rapidly.

Effects of salinity and substrate on magnitude changes of vegetative growth

\section{Plant height}

With increasing concentration of $\mathrm{NaCl}$, the rate of increase in the height was diminished (Fig. 1a). This response coincides with the results of Chartzoulakis et al. (2000) for hybrids of pepper (Capsicum annum L.) established in a mixture of perlite and sand $(1: 3 \mathrm{v} / \mathrm{v})$, and those of Bañon et al. (2005) when Nerium oleander seedlings treated with $70 \mathrm{mM} \mathrm{NaCl}$ reached only $28 \%$ of the control. Ali-Dinar et al. (1999) also observed reduction in the rates of shoot longitudinal growth in guava (Psidium guava $\mathrm{L}$.) under $30 \mathrm{mM} \mathrm{NaCl}$ which was attributed to osmotic and nutritional disbalances (Geenway and Munns, 1980). Decrease in the osmotic potential of plant cell under salt stress often leads to malfunctioning of the enzymatic system, reducing $\mathrm{CO}_{2}$ fixation and $\mathrm{N}$ assimilation, and, consequently, a shortage in plant structural material (Aslam et al., 1984).

Plants established in peat without $\mathrm{NaCl}$ addition developed the largest height at the end of the evaluation period, whereas plants grown in sand with $30 \mathrm{mM} \mathrm{NaCl}$ were the shortest ones (Fig. 1a). These results confirm the adequate physical, physicochemical, and biological characteristics of peat substrate consisting up to $98 \%$ of the organic material that, after Abad et al. (2005), contains activators of growth (humic substances, compounds of hormonal nature).

At three salt concentrations, no differences in plant height were observed among the plants growth in each of the substrates (Tab. 1). Plants growing in mixture substrate (soil, peat and sand) without addition of $\mathrm{NaCl}$ were significantly different from those cultivated in all other treatments. The differences in plant height between the treatments with sand and control (soil) were always more intense when compared to those for plants growing in peat or mixture of soil, peat and sand. This behavior was observed until the end of the experiment.

Severe reductions in shoot growth (Parra et al., 2007) and leaf cell expansion (Romero-Aranda et al., 2001) were observed previously in tomato plants growing in sand culture. Addition of organic matter to saline soils increases water-holding capacity, stabilizes soil structure, and alleviates salt stress (Walker and Bernal, 2007). Addition of organic matter also increases sorption of sodium (Walker and Bernal, 2007) and boron (Marschner, 2002), thus limiting their influence on root growth in tomato. Therefore, better growth of lulo plants in soil than in sand (Fig. 1a) may be explained by lowering availability of sodium and chlorine in the rhizosphere of soil-grown plants.

\section{Leaf number}

As salt concentration increased, the number of leaves decreased (Fig. 1b). Old leaves in plants subjected to 30 and 60 $\mathrm{mM} \mathrm{NaCl}$ had intervenal chlorosis. These symptoms, however, were not observed in young leaves, which corroborate the results of Ebert et al. (1999). In contrast, Muñoz-Ramos et al. (2004) evaluated salinity $\left(\mathrm{NaCl}, \mathrm{Na}_{2} \mathrm{SO}_{4}\right)$ effect on the growth and early development of 'California' pepper shown in perlite B12, observed 
that these salts did not affect the number of leaves. Definitely, in lulo, the reduced node number (Fig. 1c) in increasing salt concentration treatments affected leaf production.

Lulo plants grown in peat and substrate mixture without addition of $\mathrm{NaCl}$ presented the highest leaf number along the evaluation period, whereas plants grown in sand treated with 30 $\mathrm{mM} \mathrm{NaCl}$ developed the fewest number of leaves (Fig. 1b).

The treatment with peat presented the highest and lowest values of leaf abscission in the experiment: with $30 \mathrm{mM} \mathrm{NaCl}$ only $34.65 \%$ of leaves were abscised and with $60 \mathrm{mM}$ of $\mathrm{NaCl}$ $77.45 \%$ defoliation was observed. In accordance with Munns et al. (1995), the saline conditions accelerated the ageing of old leaves because the continued transportation of salts inside the transpiring leaves during the long periods of time might result in high concentrations of $\mathrm{Na}^{+}$and $\mathrm{Cl}^{\square}$, leading them to final abscission. The ratio of leaf death is crucial for plant survival (Munns et al., 1995). If more leaves are continuously produced than dying, there will be a sufficient leaf number to photosynthate. Munns (2003) clarified that salts alone are not stored inside the tissue in concentrations that inhibit growth: meristematic tissues are fed by the phloem, of which salts are excluded effectively. Also Tadeo (2000) stated that $\mathrm{NaCl}$ stress caused accumulation of $\mathrm{Na}$ and $\mathrm{Cl}$ ions in the leaf tissue inducing leaf senescence and abscission.

Reduction in leaf area is a sensitive parameter of salt stress in tomato, responsible for a decrease in leaf dry weight in salt-affected plants (Walker and Bernal, 2007). Reduction in leaf growth rate may be explained by a reduction in cell turgor, changing cell wall rheological properties, or reduction in photosynthetic rate. Also, a reduction of photosynthetic rate in tomato plants under salt stress was less sensitive to salt concentration compared to leaf area expansion (Walker and Bernal, 2007). Toxic accumulation of $\mathrm{Na}$ and $\mathrm{Cl}$ in leaves correlated with the rate of stomata closure that might limit the amount of photoassimilate production and results in lower shoot and root growth (Romero-Aranda et al., 2001).

\section{Node number}

Node number was the highest in lulo plants growing in the three substrates without $\mathrm{NaCl}$ addition along the evaluation period. The lowest values were shown by the plants growing in sand with $30 \mathrm{mM} \mathrm{NaCl}$ (Fig. 1c). Plants in this treatment had significantly fewer nodes compared to those grown in peat without salt addition (Fig. 1c, Tab. 1). There was no statistical difference in node number among the substrate treatments indicating that differences in plant height between them were caused by the reduction of internode length. Probably, severely affected leaf growth influenced gibberellin production by which the internode growth could have been decreased (Salisbury and Ross, 1994).

\section{Leaf area}

With increasing salt concentration in the different substrates, leaf area growth rate per plant decreased progressively (Fig. 2a). A reduction in leaf area expansion under saline stress was also observed by Chartzoulakis et al. (2000) and Muñoz-Ramos et al. (2004) in pepper and Saied et al. (2003) in strawberry. This effect was attributed by Cramer et al. (2001) to a decrease of leaf cellular expansion, whereas Ali-Dinar et al. (1999), Saied et al. (2003) and Ebert et al. (1999) stated that leaf area was reduced as a consequence of physiological disorders triggered by salt stress, accumulation of $\mathrm{Na}^{+}$and $\mathrm{Cl}^{\%}$ in different plant tissues, as well as by reduction of net photosynthesis rate and pigment contents in leaf tissue. Sodium can facilitate accumulation of nitrites in plant tissue that, in turn, originates toxic effects and slow assimilation of nitrogen (Navarro and Navarro, 2000) affecting leaf area growth. On the other hand, lulo plants could have decreased leaf area expansion as a water saving measure (Dodd and Davies, 2004), taking into account that salt treated plants absorbed less water than the untreated ones (Marschner, 2002).

Lulo plants grown in peat without $\mathrm{NaCl}$ developed the highest leaf area, whereas those established in sand with $30 \mathrm{mM}$ $\mathrm{NaCl}$ had statistically the lowest values of this parameter. The percentage of leaf area lowering corresponded to $10.0 \%$ in plants grown in peat with $30 \mathrm{mM} \mathrm{NaCl} ; 44.1 \%$ in peat with $60 \mathrm{mM} \mathrm{NaCl}$; $17.7 \%$ in substrate mixture of soil, peat and sand with $30 \mathrm{mM}$ $\mathrm{NaCl}$, and $19.3 \%$ in substrate mixture with $60 \mathrm{mM} \mathrm{NaCl}$.

\section{Total dry matter (DM)}

As the concentration of salt increased in any substrate, the production of plant biomass was reduced (Fig. 2b), coinciding with other investigations (Ebert et al., 1999, Chartzoulakis et al., 2000; Ferreira et al., 2002; Bayuelo-Jiménez et al., 2003). Lulo plants grown in peat and substrate mixture accumulated the highest total DM, whereas plants grown in sand built up the lowest DM. Possibly, low cation exchange $(20-50 \mathrm{mmol} / \mathrm{cg}$ ) and moisture (39\% volume) capacities of sand, as compared to 1000 $2000 \mathrm{mmol} / \mathrm{kg}$ and $61 \%$ volume of those, respectively, in peat, reduced growth and biomass production of lulo because sand does not have sufficient buffer capacity to protect plants against changes in nutrient content and $\mathrm{pH}$ (Hanan, 1998).

Richards (1992) and Bohra and Doerffling (1993) explained that plants growing in a medium rich in salts present hydric and/ or ionic disbalances that cause decrease in transpiration, photosynthesis, translocation and respiration processes, and, consequently, growth and productivity. In pepper subjected to high salinity, Lycoskoufis et al. (2005) supposed that growth restriction predominantly was caused by a reduced stomatal conductance, while after a long-term exposure to salinity growth may be also suppressed due to inhibition of photosynthesis at chloroplast level.

This behavior might indicate that reduction in vegetable growth under saline conditions is a primary adaptation to the restriction in water availability due to the low osmotic potential that prevails in the external medium (Pasternak, 1987; Sonneveld, 2000), and also due to limitations derived from the nutritional disbalance (Grattan and Grieve, 1999).

\section{Shoot: root ratio (SRR)}

During the evaluation period, plants SRR in all treatments had an ascendant behavior (Fig. 3). Plants grown in substrate 
mixture with $60 \mathrm{mM} \mathrm{NaCl}$ had the highest SRR at the end of the experiment. With increasing salt concentrations, SRR increased in plants established in peat and substrate mixture.

Assuming $0 \mathrm{mM} \mathrm{NaCl}$ (unsalinized substrate) as $100 \%$ in the respective substrate, plants grown in peat with 30 and 60 $\mathrm{mM} \mathrm{NaCl}$ increased their SRR by 22,9 and $44,4 \%$, respectively, whereas this increase for the substrate mixture was 9,0 and $89,4 \%$, respectively, at 30 and $60 \mathrm{mM} \mathrm{NaCl}$. Nevertheless, in accordance with the obtained specific leaf area (SLA) (Flórez, 2006), it is deduced that the DM gain was conducted for the stem growth, but not for the leaf growth. High salinity also lowers water potential in the plant cells (Cuartero and Fernandez-Munoz, 1999), including root cells that, in turn, reduces water flow into the root and the rate of root growth. Other reasons for reduced root growth under saline stress may include interference of salt ions with plant nutrients and their accumulation in root cells leading to plant death (Cuartero and Fernandez-Munoz, 1999).

In sand, a slowly decreased SRR was observed when $\mathrm{NaCl}$ concentration was increased up to $30 \mathrm{mM}$, which agrees with the results obtained by Imas and Feigin (1995) in sweet corn and Bayuelo-Jiménez et al. (2003) in four Phaseolus species. Also Savvas (2001) stated that there is a general consensus among the experimental results of many investigators that moderate levels of salinity affect the above-ground growth more than the root growth. To explain this opposite behavior of SRR, it should be taken into account that in $30 \mathrm{mM} \mathrm{NaCl}$ treatment in sand: (a) above ground growth was the lowest one among all treatments; (b) in spite of the negative effect of salt on the roots, root growth in lulo appears to be less affected by salt than shoot growth, similarly to tomato plants (Cuartero and FernándezMuñoz, 1999); (c) a greater proportion of assimilates allocated to the roots and less to the shoot, as compared to control plants, could have influenced the decreased SRR of this treatment (PérezAlfocea et al., 1996).

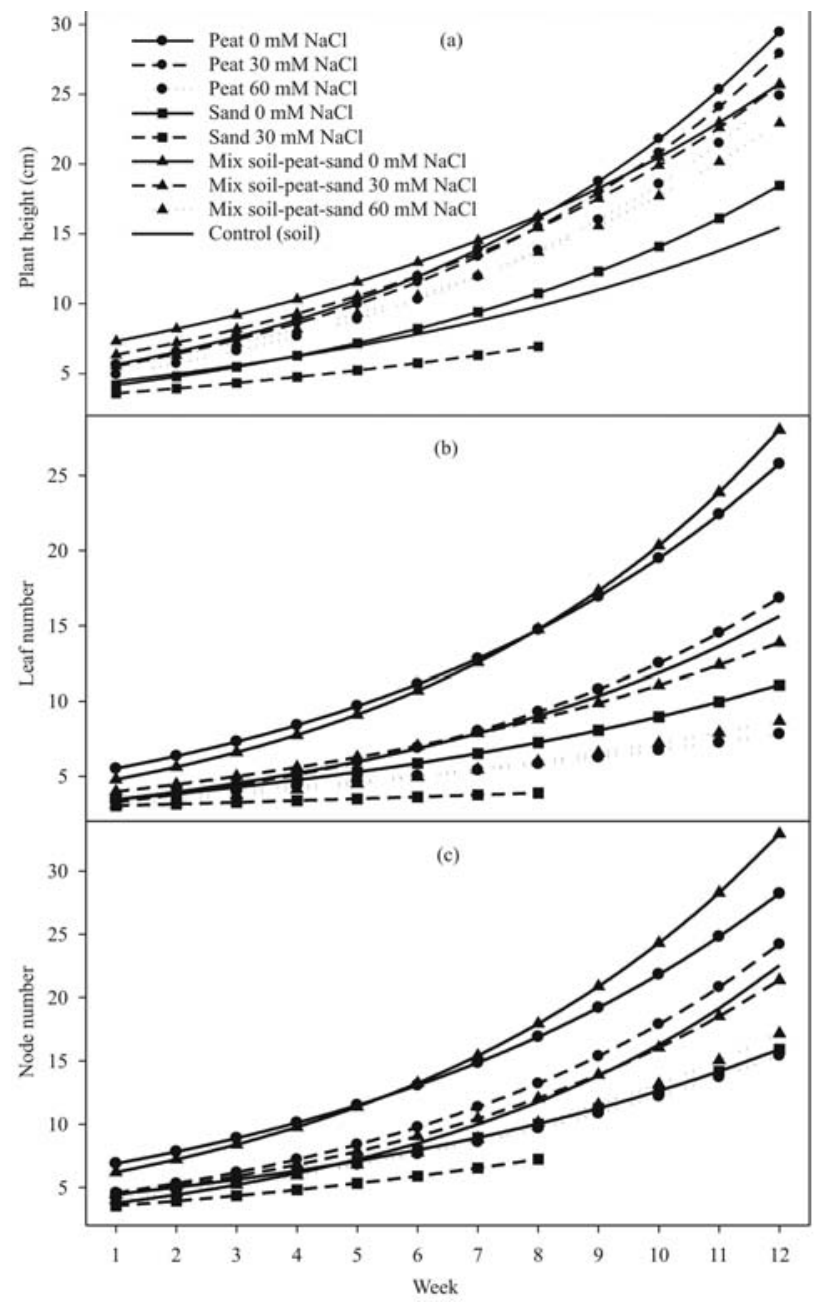

FIGURA 1- Effects of the substrate (peat, sand or a mixture of soil, peat and sand 3:1:1 (w/w)) and salinity $(0,30$, or $60 \mathrm{mM} \mathrm{NaCl}$ ) on changes of (a) plant height, b) leaf number and c) node number of lulo plants.

TABLE 1 - Confidence intervals of $b$ coefficient for the adjusted curve in plant height, leaf number, node number, leaf area and total dry matter in lulo plants.

\begin{tabular}{l|c|c|c|c|c|c|c|c|c|c|c}
\hline \multirow{2}{*}{ Treatment } & \multicolumn{9}{|c|}{ Plant height } & \multicolumn{9}{c|}{ Leaf number } & \multicolumn{2}{c|}{ Node number } & \multicolumn{2}{c|}{ Leaf area } & \multicolumn{2}{c}{ Total DM } \\
\cline { 2 - 10 } & \multicolumn{9}{|c|}{ Confidence intervals } \\
\cline { 2 - 11 } & Low. & Upp. & Low. & Upp. & Low. & Upp. & Low. & Upp. & Low. & Upp. \\
& Limit & Limit & limit & limit & limit & limit & Limits & Limit & limit & Limit \\
\hline 1) Peat 0 mM NaCl & 4.187 & 5.514 & 3.278 & 6.329 & 4.148 & 7.953 & 96.83 & 241.0 & 1.065 & 2,200 \\
2) Peat 30 mM NaCl & 4.142 & 5.423 & 1.413 & 4.243 & 2.928 & 4.926 & 73.17 & 185.9 & 0.936 & 2.030 \\
3) Peat 60 mM NaCl & 3.640 & 4.874 & 1.608 & 4.854 & 2.634 & 4.947 & 49.95 & 240.0 & 0.429 & 1.793 \\
4) Sand 0 mM NaCl & 3.077 & 4.237 & 2.298 & 3.935 & 3.100 & 4.855 & 19.82 & 38.01 & 0.295 & 0.765 \\
5) Sand 30 mM NaCl & 2.832 & 3.698 & 2.495 & 3.386 & 2.678 & 3.731 & 3.962 & 22.16 & 0.151 & 0.390 \\
7) Mix. soil-peat- & & & & & & & & & & \\
sand 0 mM NaCl & 5.527 & 7.526 & 2.936 & 5.225 & 4.156 & 6.483 & 96.38 & 249.6 & 1.260 & 3.165 \\
8) Mix. soil-peat- & & & & & & & & & & \\
sand 30 mM NaCl & 4.981 & 6.204 & 1.802 & 5.313 & 2.584 & 5.063 & 35.58 & 135.8 & 1.147 & 2.815 \\
9) Mix. soil-peat- & & & & & & & & & & \\
sand 60 mM NaCl & 4.196 & 5.544 & 1.420 & 4.253 & 2.560 & 4.439 & 37.62 & 150.9 & 0.528 & 1.529 \\
10) Control (soil) & 3.531 & 4.404 & 1.677 & 4.337 & 2.314 & 4.073 & 1.163 & 11.65 & 0.016 & 0.253 \\
\hline
\end{tabular}

*The ranges between lower and upper limit correspond to $95 \%$ of coefficiente $b$ confidence intervals estimated in the exponential model. Accordingly, ranges that not overlap indicate that treatments are significantly different $(\mathrm{P} \leq 0.05)$. 


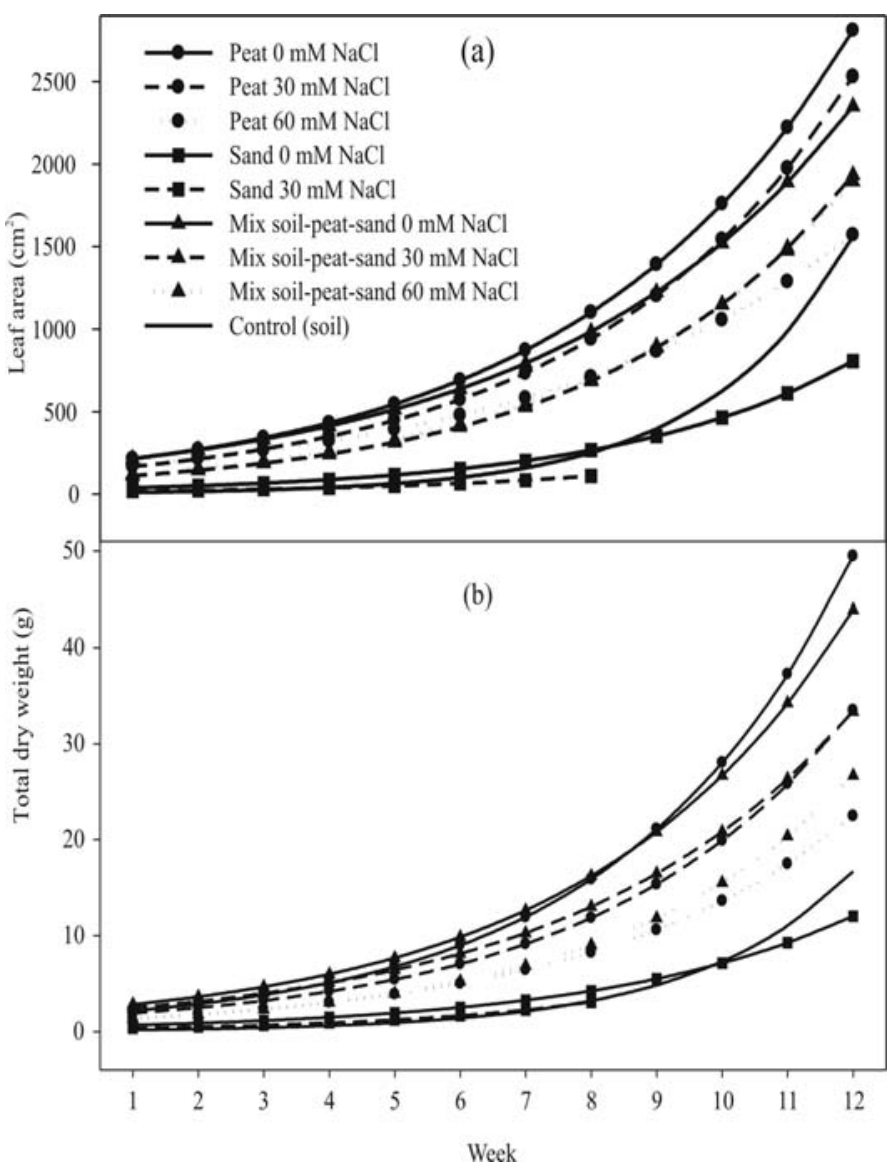

FIGURA 2 - Effects of the substrate (peat, sand or a mixture of soil, peat and sand 3:1:1 (w/w)) and salinity $(0,30$, or $60 \mathrm{mM} \mathrm{NaCl}$ ) on changes of (a) leaf area and (b) dry matter accumulation of lulo plants.

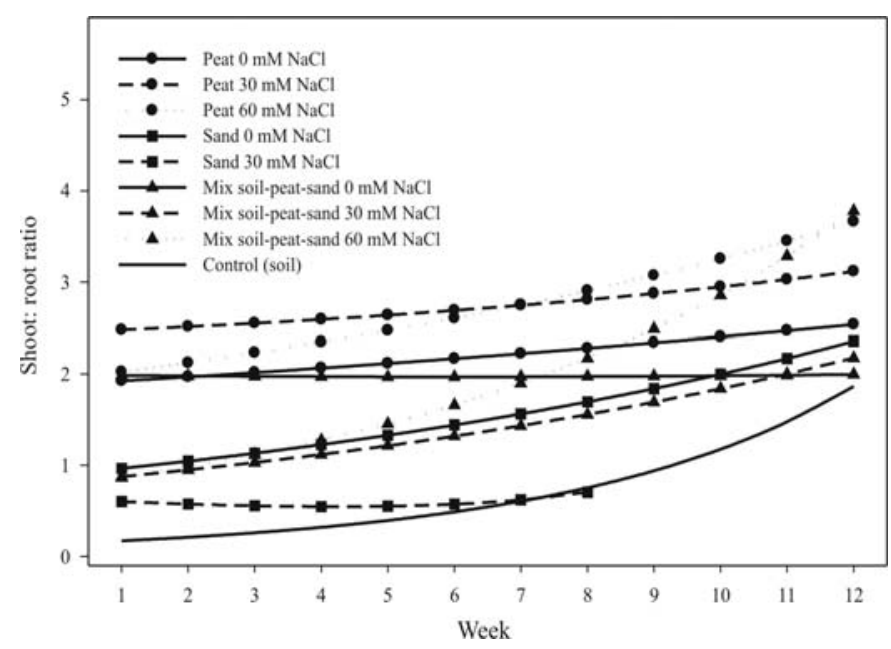

FIGURA 3 - Effects of the substrate (peat, sand or a mixture of soil, peat and sand 3:1:1 (w/w)) and salinity $(0,30$, or $60 \mathrm{mM} \mathrm{NaCl}$ ) on the shoot: root ratio of lulo plants.

\section{CONCLUSIONS}

1-A reduction of plant height, number of leaves and nodes, leaf area and plant DM with increasing $\mathrm{NaCl}$ concentrations in the substrates was observed in lulo plants.

2-The increase of shoot/root ratio in lulo plants with increased salinity indicates slow growth of roots in salinized substrates.

3-Due to the inappropriate physical and physicochemical properties of sand as a substrate for salinized solutions, lulo plants growing in this medium were most affected.

\section{REFERENCES}

ABAD, M: NOGUERA, P; CARRIÓN, C. Sustratos para el cultivo sin suelo y fertiirrgiación. In: CADAHÍA, C. (Ed.). Fertirrigación: cultivo hortícolas, frutales y ornamentales. Madrid: Ediciones Mundi-Prensa, 2005. p.299-354.

ALI-DINAR, H.M.; EBERT, G.; LÜDDERS, P. Growth, chlorophyll content, photosynthesis and water relations in guava (Psidium guava L.) under salinity and different nitrogen supply. Gartenbauwissenschaft, Stuttgart, v.64, n.2, p.54-59, 1999.

ANGULO, R. Lulo: el cultivo. Bogotá: Fundación Universidad de Bogotá Jorge Tadeo Lozano, 2006. 100p.

ASLAM, M.; HUFFAKER, R.C.; RAINS, D.W. Early effect of salinity on nitrate assimilation in barley seedlings. Plant Physiology, Washington, n.76, p.321-325, 1984.

BAÑON, S.; FRNÁNDEZ, J.A.; OCHOA, J.; SANCHEZ-BLANCO, M.J. Paclobutrazol as an aid to reduce some effects of salt stress in oleander seedlings. European Journal of Horticultural Science, Stuttgart, v.70, n.1, p.43-49, 2005.

BAYUELO-JIMÉNEZ, J.S.; DEBOUCK, D.G.; LYNCH, J.P. Growth, gas exchange, water relations, and ion composition of Phaseolus species grown under saline conditions. Field Crops Research, New York, v.80, p.207-222, 2003.

BOHRA, J.S.; DOERFFLING, K. Potassium nutrition of rice (Oryza sativa $\mathrm{L}$.) varieties under $\mathrm{NaCl}$ salinity. Plant and Soil, Dordrecht, v.152, p.299-303, 1993.

CHARTZOULAKIS, K.S.; KLAPAKI, G.; SONNEVELD, C. Effects of $\mathrm{NaCl}$ salinity on growth and yield of two pepper cultivars. Acta Horticulturae, Wageningen, v.511, p.143-149, 2000.

CRAMER, G.R.; SCHMIDT, C.L.; BIDART, C. Analysis of cell wall hardening and cell wall enzymes of salt-stressed maize (Zea mays) leaves. Australian Journal of Plant Physiology, Collingwood, v.28, p.101-109, 2001.

CUARTERO, J.; FERNANDEZ-MUNOZ, R. Tomato and salinity. 
Sciencia Horticulturae, Amsterdam, v.78, p.83-125, 1999.

DODD, I.C.; DAVIES, W.J. Hormones and the regulation of water balance. In: DAVIES, P.J. (Ed.). Plant hormones: biosynthesis, signal transduction, action! Dordrecht: Kluwer Academic Publication, 2004. p.493-512.

EBERT, G. Salinity problems in (sub-) tropical fruit production. Acta Horticulturae, Wagningen, v.531, p.99-105, 2000.

EBERT, G.; CASIERRA, F.; LÜDDERS, P. 1999. Influence of $\mathrm{NaCl}$ salinity on growth and mineral uptake of lulo (Solanum quitoense L.). Journal of Applied Botany, Berlin, v.73, p.31-33.

FERREIRA, E.; WILLADINO, L.; SEMEN, L.S.; RANGEL,T.; OLIVEIRA E SILVA, S. Genotipos de bananos (Musa spp.) bajo estrés salino: tolerancia y sensibilidad. Infomusa, Montpellier, v.11, n.2, p.13-18, 2002.

FLÓREZ, S.L. Efecto de la salinidad (NaCl) sobre el crecimiento y la dinámica de nutrientes en la fase vegetativa del cultivo del lulo (Solanum quitoense Lam.), en diferentes sustratos. 2006. $38 \mathrm{f}$. Thesis (Ingeniera Agronomía) - Facultad de Agronomía, Universidad Nacional de Colombia, Bogotá, 2006.

GRATTAN, S.R., GRIEVE, C.M. Mineral nutrient relations in horticultural crops. Scientia Horticulturae, Amsterdam, v.78, n.127-157, 1999.

HANAN, J.J. Greenhouses: advanced technology for protected horticulture. Boca Raton: CRC Press, 1998.

HUNT, R. Plant growth curves: the functional approach to plant growth analysis. London: Edward Arnold Publication, 1982.

IMAS, P.; FEIGIN, A. Yield and water use efficiency of sweet corn grown in solution culture as affected by $\mathrm{KNO}_{3}$ and salinity levels. Acta Horticulturae, Wageningen, v.401, p.301-308, 1995.

LYCOSKOUFIS, I.H; SAVVAS, D.; MAVROGIANOPOULOS, G. Growth, gas exchange, and nutrient status in pepper (Capsicum annuum L.) grown in recirculating nutrient solution as affected by salinity imposed to half of the root system. Scientia Horticulturae, Amsterdam, v.106, p.147-161, 2005

MARSCHNER, H. Mineral nutrition of higher plants. Amsterdam: Academic Press, 2002. p.657-680.

MUNNS, R. The impact of salinity stress. Canberra, Australia: CSIRO Division of Plant Industry, 2003.

MUNNS, R. Physiological processes limiting plant growth in saline soils: some dogmas and hypotheses. Plant, Cell and
Environment, Oxford, v.16, p.15-24, 1993.

MUNNS, R.; SCHACHTMAN, D.P.; CONDON, A.G.. The significance of a two-phase growth response to salinity in wheat and barley. Australian Journal of Plant Physiology, Collingwood, v.22, p.561-569, 1995.

MUÑOZ-RAMOS, J.J.; GUZMÁN, M.; CASTELLANOS, J.Z. Salinidad sódica en el desarrollo vegetativo y reproductivo del pimiento. Terra, Chapingo, v.22, n.2, p.187- 196, 2004.

NATIONAL RESEARCH COUNCIL. Lost crops of the Incas. Washington, D.C.: National Academy Press, 1989. p.267-275.

NAVARRO, S.; NAVARRO, G. Química agrícola: el suelo y los elementos químicos esenciales para la vida vegetal. Madrid: Ediciones Mundi-Prensa, 2000. 487p.

PARRA, M., ALBACETE, A., MARTINEZ-ANDUJAR, C.; PEREZ-ALFOCEA, F. Increasing plant vigour and tomato fruit yield under salinity under inducing plant adaptation at the earliest seedling stage. Environmental and Experimental Botany, Kidlington, v.60, p.77-85, 2007.

PASTERNAK, D. Salt tolerante and crop production - A comprehensive approach. Annual Review of Phytopathology, Palo Alto, v.25, p.271-291,1987.

PÉREZ-ALFOCEA, F.; BALIBREA, M.E.; SANTA CRUZ, A.; ESTAN, M.T. Agronomical and physiological characterization of salinity tolerance in a commercial tomato hybrid. Plant and Soil, Dortrecht, v.180, p.251-257. 1996.

RAINS, D.W.; GOYAL, S.S. Strategies for managing crop production in saline environments: An overview. Journal of Crop Production, Binghamton, v.7, n.1-2, p.1-10, 2003.

RICHARDS, F.A. Increasing salinity tolerance of grain crops: it is worthwile? Plant and Soil, Dordrecht, v.146, p.89-98, 1992.

ROMERO-ARANDA, R.; SORIA, T.; CUARTERO, J. Tomato plant water uptake and plant-water relationships under saline growth conditions. Plant Science, Limerick, v.160, n.2, p.265$272,2001$.

SAIED, A.S.; KEUTGEN, N.; NOGA, G. Effects of NaCl stress on leaf growth, photsynthesis and ionic contents of strawberry cvs. 'Elsanta' and 'Korona'. Acta Horticulturae, Wageningen, v.609, p.67-73, 2003

SAVVAS, D. Nutritive management of vegetables and ornamental plants in hydroponics. In: Dris, R.; Niskanen, R.; Jain, S.R. (Eds.). Crop management and postharvest handling of horticulture products. Enfield, NH: Science Publishers, 2001. v.1, p.37-87. 
SALISBURY, F.B.; ROSS, C.W. Fisiología vegetal. México: Grupo Editorial Iberoamérica, 1994. 759p.

SONNEVELD, C. Effects of salinity on substrate grown vegetables and ornamentals in greenhouse horticulture. 2000. Thesis (PhD) - University of Wageningen, Wageningen, 2000.

TADEO, F.R. Fisiología de las plantas y el estrés. In: AZCÓNBIETO, J.; TALÓN, M. (Eds.). Fundamentos de fisiología vegetal. Madrid: McGraw-Hill/Interamericana de España, 2000. p.481-498.
TAFUR, R. Propuesta frutícola para Colombia y su impacto en la actividad económica nacional, regional y departamental. In: FISCHER, G.; MIRANDA, D.; PIEDRAHITA, W.; MAGNITSKIY, S. (Eds.). Memorias primer congreso colombiano de horticultura. Bogotá: Unibiblos, 2006. p.4766.

WALKER, D.J.; BERNAL, M.P. The effects of olive waste mill compost and poultry manure on the availability and plant uptake of nutrients in a highly saline soil. Bioresource Technology, Amsterdam. In press 